\title{
Molecular epigenetics in the management of ovarian cancer: are we investigating a rational clinical promise?
}

\author{
Ha T. Nguyen ${ }^{1 \dagger}$, Geng Tian ${ }^{1,2 \dagger}$ and Mandi M. Murph ${ }^{1 *}$ \\ ${ }^{1}$ Department of Pharmaceutical and Biomedical Sciences, University of Georgia College of Pharmacy, Athens, GA, USA \\ ${ }^{2}$ Department of Obstetrics and Gynecology, The Second Hospital of Jilin University, Changchun, China
}

\section{Edited by:}

Ivan Garcia-Bassets, University of California San Diego, USA

\section{Reviewed by:}

Miriam Reuschenbach, University Hospital Heidelberg, Germany

Ivan Garcia-Bassets, University of California San Diego, USA

\section{*Correspondence:}

Mandi M. Murph, Department of Pharmaceutical and Biomedical Sciences, University of Georgia College of Pharmacy, 240 West, Green Street, Athens, GA 30602, USA e-mail:mmurph@uga.edu

${ }^{+}$Ha T. Nguyen and Geng Tian have contributed equally to this work.
Epigenetics is essentially a phenotypical change in gene expression without any alteration of the DNA sequence; the emergence of epigenetics in cancer research and mainstream oncology is fueling new hope. However, it is not yet known whether this knowledge will translate to improved clinical management of ovarian cancer. In this malignancy, women are still undergoing chemotherapy similar to what was approved in 1978, which to this day represents one of the biggest breakthroughs for treating ovarian cancer. Although liquid tumors are benefiting from epigenetically related therapies, solid tumors like ovarian cancer are not (yet?). Herein, we will review the science of molecular epigenetics, especially DNA methylation, histone modifications and microRNA, but also include transcription factors since they, too, are important in ovarian cancer. Pre-clinical and clinical research on the role of epigenetic modifications is also summarized. Unfortunately, ovarian cancer remains an idiopathic disease, for the most part, and there are many areas of patient management, which could benefit from improved technology. This review will also highlight the evidence suggesting that epigenetics may have pre-clinical utility in pharmacology and clinical applications for prognosis and diagnosis. Finally, drugs currently in clinical trials (i.e., histone deacetylase inhibitors) are discussed along with the promise for epigenetics in the exploitation of chemoresistance. Whether epigenetics will ultimately be the answer to better management in ovarian cancer is currently unknown; but we hope so in the future.

Keywords: microRNA, ovarian cancer, epigenetics, DNA methylation, histone modifications

\section{INTRODUCTION TO EPIGENETIC MODIFICATIONS}

Although genetic alterations, such as gene copy-number variations, contribute to the development of cancer, classical genetics alone does not account for all acquired characteristics of cancer cells. For this reason, it is generally appreciated that epigenetic abnormalities are involved in tumorigenesis. The definition of epigenetics is the potentially permanent and heritable change in gene expression, which is not attributed to any alteration in the underlying DNA sequence, but results from structural adaptations and responsive outcomes on chromosome regions $(1,2)$. Epigenetic modifications among cancer cells result in aberrant gene expression via DNA methylation, histone modifications, and noncoding microRNAs (miRNAs) and can also include alterations among transcription factors (3), although the latter is less often emphasized in epigenetics. These modifications are associated with initiation and progression of ovarian cancers (Figure 1).

DNA methylation is the most frequently studied epigenetic phenomenon. DNA methylation occurs among cytosine residues in cytosine-guanine $(\mathrm{CpG})$ dinucleotides, which are mostly distributed in the CpG-rich regions referred to as "CpG islands" (4). This type of methylation is achieved by DNA methyltransferases (DNMTs), which are a family of enzymes that serve to transfer methyl groups onto DNA (5). In humans, DNMTs are divided into two groups: DNMT1 and DNMT3.

Changes in DNA methylation regulating gene expression are widespread, appearing in both normal and cancerous cells. For example, roughly $80 \%$ of $\mathrm{CpG}$ dinucleotides in the human genome are subject to methylation changes throughout life. In addition, nearly $70 \%$ of all $\mathrm{CpG}$ islands are methylated at any given time (6). Furthermore, in normal cells, DNA methylation regulates the silenced allele of imprinted genes and also represses expression of potentially harmful DNA transposon sequences (7). Interestingly, alterations and deregulation of epigenetic events precede the transformation that generates cancer cells (8).

\section{EPIGENETIC MODIFICATIONS IN CANCER}

Among cancer cells, DNA hyper-methylation is associated with gene silencing and DNA hypo-methylation with gene expression, both of which are widespread characteristics of malignancy (Figure 2). Most often, hypermethylated CpG islands within the DNA silence critical tumor suppressor genes, wrecking havoc on the cell's ability to repair DNA damage, control cell growth, and inhibit proliferation. On the other hand, DNA hypo-methylation contributes to oncogenesis when previously silenced oncogenes become transcriptionally activated. In addition, DNA hypo-methylation can activate latent transposons and cause chromosomal instability in specific pericentromeric satellite regions (9-14).

Histone modifications also play important roles in epigenetic regulation. Histones are dynamic proteins that can become methylated or acetylated on specific amino acid residues, which correlates with active or repressive transcription $(15,16)$. An octamer 


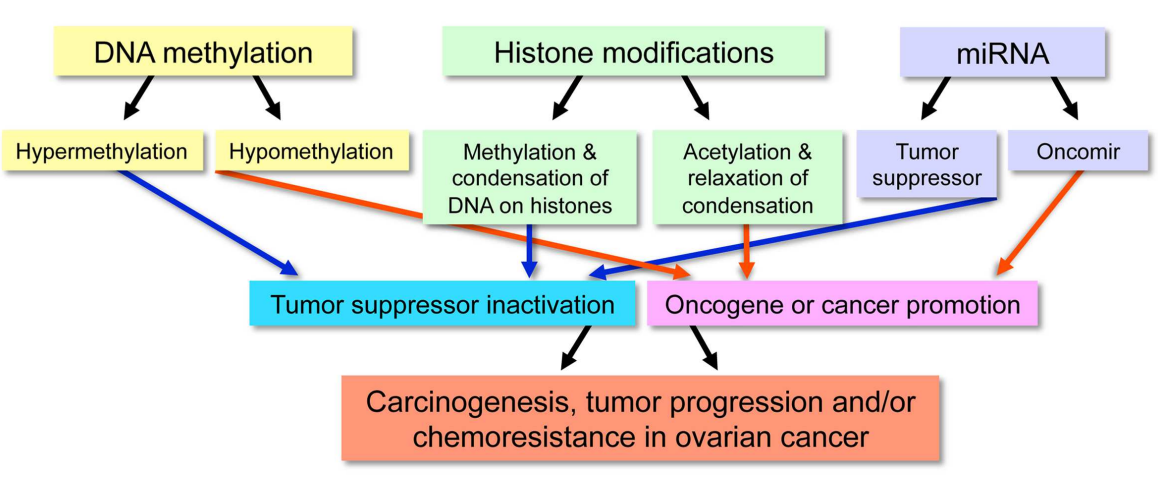

FIGURE 1 | Outline of the functional effect resulting from specific epigenetic modifications in malignancy.

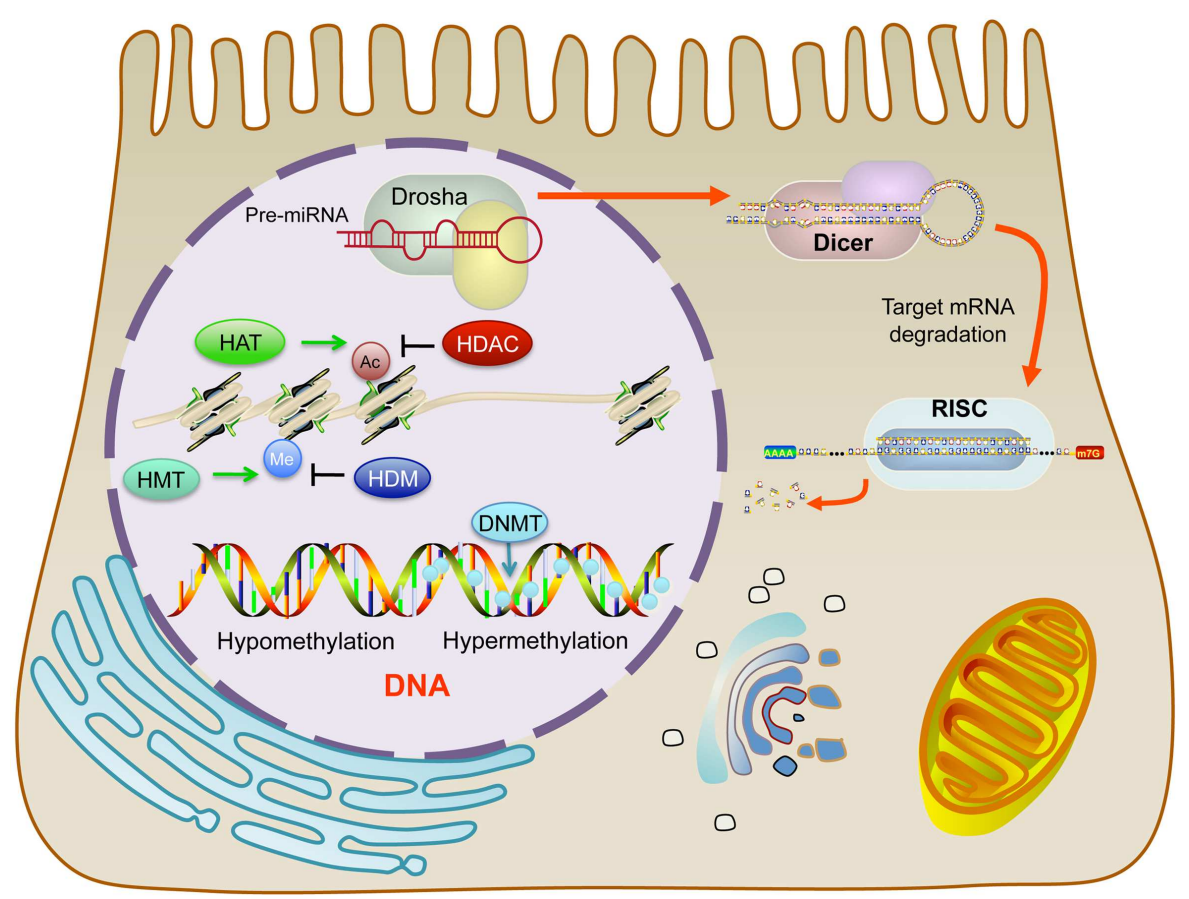

FIGURE 2 | Location of molecular epigenetic mechanisms dynamically affecting gene expression.

of histones make up the nucleosome, which is the fundamental building-block unit of chromatin. The nucleosome contains lysine-rich histone tails extending outward from the four constituent core histone proteins ( $\mathrm{H} 2 \mathrm{~A}, \mathrm{H} 2 \mathrm{~B}, \mathrm{H} 3$, and $\mathrm{H} 4)$. These histone tails provide sites for reversible modifications to alter chromatin structure and thus, gene expression. By tightly winding and condensing chromatin or loosening up the structure of chromatin, transcription factors and other proteins are prevented or permitted access to the DNA for transcription, respectively. The target residues of histone modifications are lysine (acetylation, methylation, and ubiquitination), arginine (methylation), and serine and threonine (phosphorylation). The crosstalk between histone modifications is complicated and varied based on chromosomal domains.
Overall, the combination of histone modifications contributes largely to chromatin pattern and gene expression (17). In general, histone acetylation adds more negative charges to positive lysine, thus loosening the electrostatic interaction between histones and the DNA backbone. For this reason, the condensation of chromatin is partially regulated by histone deacetylases (HDAC), a class of deacetylating enzymes that remove acetyl groups from lysine residues of histones, ultimately causing the repression of gene expression $(18,19)$. If methylation also targets the same lysine residue, which means excluding acetylation, the histone methylation will have the opposite effect, compared to acetylation, and repress gene expression. However, it is not an all-encompassing rule for every single case. In fact, the situation is much more intriguing. Indeed, methylation can 
block repressive factors and act as a transcription-facilitating element (20).

The extent of methylation status (mono-, di-, and trimethylation) and other types of histone modifications (phosphorylation or ubiquitination) are involved in a network of sophisticated crosstalk, determining chromatin condensation status (17). Furthermore, histone $\mathrm{H} 3$ phosphorylation is also suggested to interfere with the electrostatic interaction between histones and the DNA backbone, thus favoring transcription factor-induced gene expression (21). (Other types of histone modifications, such as ubiquitination and SUMOylation, are not discussed in this review.) To further convolute this process, evidence suggests that regulating gene expression may occur through crosstalk between histone modifications and DNA methylations (22-24).

MicroRNAs are small, non-coding RNAs, which are about 18-25 nucleotides in length. They negatively regulate gene expression through complementary binding to the $3^{\prime}$ UTR region in the promoter of targeted mRNAs, leading to mRNA degradation or translational repression, which is dependent on the level of complementarities $(25,26)$. Because of their unique functions, miRNAs regulate many biological changes and contribute to cancer progression. For instance, studies comparing miRNA profiles between normal and cancerous specimens identified alterations of multiple miRNA during cancer development and progression $(27,28)$. MicroRNAs can have dual roles in cancer progression, as tumor suppressors that repress oncogenes or as tumorigenesis factors that deregulate tumor suppressor genes (29).

\section{EPIGENETIC CHANGES IN OVARIAN CANCER}

\section{Role of DNA methylation in the development of malignancy}

As previously stated, DNA methylation can prevent the transcription of tumor suppressor genes. Examples of this occurrence in ovarian cancer include the human MutL homolog 1 ( hMLH1) and breast cancer susceptibility gene 1 (BRCA1), which are two critical genes that transcribe proteins involved in the DNA damage response and DNA mismatch repair. These processes are critical in maintaining a stable chromosome and fixing damage. In ovarian cancer, the promoter regions of genes encoding these two proteins are hypermethylated, leading to the low expression levels of hMLH1 and BRCA1 $(30,31)$. Indeed, women with genetic mutations in BRCA1/2 are susceptible to breast, ovarian, and (sometimes) pancreatic cancer (32) due to this aberration. Among older women with ovarian cancer, tumors are hypermethylated, leading to suppression in transforming growth factor (TGF)-beta pathway activity (33). Other silenced genes in ovarian cancer include Ras-association domain gene family 1A (RASSF1A), lost on transformation 1 (LOT1), death-associated protein kinase (DAPK), target of methylation-induced silencing (TMS1)/apoptosis specklike protein containing a CARD (ASC) (34-37), and insulin-like growth factor binding protein (IGFBP-3) (38). These genes encode proteins involved in regulation of the cell cycle and the promotion of apoptosis, which are important to maintain homeostasis.

\section{Role of histone modifications in malignant tumorigenesis}

Carcinogenesis and tumorigenesis are multifaceted; how normal tissue precisely undergoes stepwise changes to yield ovarian cancer and then how that progresses unregulated by mechanistic controls is largely debated. However, many aspects involved in the progression of ovarian malignancy are reported, including the role of histones in this process. For example, normal epithelial ovarian cells repress the expression of claudin-3 and claudin-4, yet these proteins are highly overexpressed in ovarian cancer. For claudin-3, this change is exclusively attributed to repressive histone marks, whereas claudin-4 repression occurs through histone modifications and DNA methylation (39). These findings explain the molecular mechanisms of repressive histone marks likely occurring during tumorigenesis; the rationale is that claudins are critical components of tight junctions and other claudin family members comprise gene signatures leading to worsened outcomes in ovarian cancer (40).

Another example of histone modifications affecting cell-cell interactions occurs in the TGF-betal receptor. This receptor is an important regulator of cell growth, cell cycle, and it also activates SMAD transcription factors. Interestingly, aberrant signaling of TGF-betal receptor results in histone modifications and repressive chromatin in ovarian cancer, which prevents the expression of ADAM19, the protein containing A Disintegrin and A Metalloprotease (41). ADAM19 is a metalloproteinase involved in cell-cell interactions and cell adhesion. Taken together, these studies suggest that histone modifications may be important epigenetic events allowing cells to alter contact with their environment.

\section{MicroRNA alterations in the malignant progression of ovarian cancer}

In ovarian cancer, miRNAs play a role in malignant progression. Evidence of this comes from reports that $37.1 \%$ of the miRNA genomic loci exhibit alterations in DNA copy-number (42). Other molecular mechanisms of miRNA deregulation include DNA methylation and histone modification of miRNA genes (43). Many profiling studies performed in ovarian cancer models illuminate abundant alterations. The results show that the miR-200 family and let-7 family are aberrantly regulated (Table 1) along with deregulated tumor suppressor miRNAs: miR-15a, miR-34a, and miR-34b $(43,44)$.

In addition to genetically related explanations for miRNA deregulation, there are also changes in regulatory proteins that affect miRNA processing machinery. For example, there is a

Table 1 |Alterations in multiple miRNAs among ovarian cancer.

\begin{tabular}{|c|c|c|c|c|}
\hline Type of cancer & Up-regulated & Down-regulated & Target & Reference \\
\hline Ovarian cancer & $\begin{array}{l}\text { miR-200 family } \\
\text { (miR-200a, } \\
\text { miR-200b, } \\
\text { miR-200c, } \\
\text { miR-141, } \\
\text { miR-429), } \\
\text { miR-214, } \\
\text { miR-21, } \\
\text { miR-141, } \\
\text { miR-221, } \\
\text { miR-146b, } \\
\text { miR-508 }\end{array}$ & $\begin{array}{l}\text { miR-199a, } \\
\text { miR-140, } \\
\text { miR-145, } \\
\text { miR-125b1, } \\
\text { miR-100, let-7b, } \\
\text { miR-125b, let-7f, } \\
\text { miR-106b, } \\
\text { miR-134, } \\
\text { miR-155, } \\
\text { miR-346, } \\
\text { miR-424 }\end{array}$ & & $(45-48)$ \\
\hline
\end{tabular}


reduction in the protein expression levels of Dicer and Drosha. These two proteins are essential factors involved in the biogenesis of miRNAs (49). A loss of one dicer allele facilitates tumorigenesis while a loss of both alleles in lethal to the cell (50). Furthermore, low expression levels of Dicer and Drosha correlates with poor clinical outcomes (49).

Significant interplay is likely between miRNAs and other molecular epigenetic mechanisms of DNA methylation and histone modifications. For instance, let-7a-3 is hypermethylated in ovarian tumor samples, and the suppression of this miRNA correlates with good prognosis (51). As another example, the down-regulation of miR-101 will de-repress its target EZH2, which is a catalytic subunit of the polycomb repression complex 2 (PRC2). Because the complex tri-methylates histone $\mathrm{H} 3$ lysine 27 , its restoration aberrantly silences multiple tumor suppression genes in cancer (45, 52, 53). MiR-140, which targets histone deacetylase 4 (HDAC4), is also reported to be down-regulated in ovarian cancer $(45,54)$.

\section{EMERGING POTENTIAL OF EPIGENETICS IN THE DIAGNOSIS OR PROGNOSIS OF OVARIAN CANCER \\ DNA METHYLATION TECHNIQUES IN OVARIAN CANCER DIAGNOSTICS AND PROGNOSTICS}

Analysis of DNA methylation status among tumor specimens is the most favored approach for developing a biomarker diagnostic/prognostic due to methylation stability, amplification ability, high-sensitivity, and relatively low cost. In fact, DNA methylation has demonstrated diagnostic and prognostic use in other types of cancers, in particular glioma (55). To detect DNA methylation, the simplest approach is to treat cells with DNA methyltransferase inhibitors (DNMTIs). The treatment will reverse the DNA methylation and result in re-expression of genes that were silenced by this mechanism. Comparison of mRNA expression levels before and after treatment will suggest candidates of methylation in cancer, which can be confirmed using additional methods. An alternative approach uses HpaII, a methylation-sensitive restriction enzyme to digest genomic DNA samples prior to the amplification of digested DNA (using PCR) to compare differences in methylation levels between samples (56). In a more straightforward way, another method uses an antibody against 5-methylcytosine to precipitate methylated DNA fragments (DNA immunoprecipitation or MetDIP) (57). Collected genomic DNA fragments are then identified with array-based comparative genome hybridization to reveal human methylome maps (58).

Despite their readiness, array-based DNA methylation analysis approaches provide limited information about the extent and pattern of methylation in specific $\mathrm{CpG}$ regions. To overcome this drawback, bisulfite sequencing methods have been developed. Bisulfite treatment converts unmethylated cytosine residues to uracil, while methylated cytosine residues stay intact. After treatment, specific primers are used in methylation-specific PCR to amplify and help differentiate unmethylated and methylated DNA regions (59). This method is used to identify the difference in DNA methylation profiles in three major types of gynecological cancers: ovarian, endometrial, and cervical cancers (60).

To date, multiple other techniques applying bisulfite treatment have been introduced for whole-genome methylation sequencing and profiling. These include bisulfite padlock probes (BSPP), solution hybrid selection bisulfite sequencing (SHBS-seq), array capture bisulfite sequencing (ACBS-seq), and bisulfite-patch PCR (61-66); comprehensive information on methylation profiling is reviewed in Ref. $(63,67)$. In ovarian cancer, MethylCapSeq for whole-genome DNA methylation profiling is a method using specific protein to capture methyl-CpG followed by highthroughput sequencing. MethylCap-Seq has been applied to analyze methylomic patterns of ovarian tumors and results suggest that hedgehog signaling pathway members (ZIC1 and ZIC4) are DNA methylation prognostic biomarkers for ovarian cancer $(68,69)$.

\section{A PROSPECTIVE OF HISTONE MODIFICATIONS IN PHARMACOLOGY}

Although histone modifications lag behind DNA methylation in this potential application, experimental data elude to future emergence for this field. In support of this concept, research indicates that the loss of $\mathrm{H} 3$ histone methylation correlates with significantly reduced overall survival in ovarian cancer patients (70). In cellbased assays, proteomic techniques have been applied to profile expression-level changes, like histone modification enzymes, after treatment with a heat shock protein 90 inhibitor (HSP90). Maloney et al. suggested that similar analyses might aid pharmacology by illuminating genes and proteins involved in drug responses (71). Indeed, in ovarian cancer cells, histone de-acetylation at the RGS10-1 promoter correlates with suppression of RGS10 and chemoresistance (72). This data suggest the possibility of using histone biomarkers to determine the appropriate selection of therapeutics, particularly in cases of ovarian cancer chemoresistance, moving toward "precision" medicine in the clinic $(72,73)$.

The growing list of experimental techniques to examine histone modifications further alludes to emerging potential. The traditional experimental techniques available include chromatin immune precipitation (ChIP), which uses antibodies specific to acetylated histone $\mathrm{H} 3$ and $\mathrm{H} 4$ to detect histone acetylation and mass spectrometry-based proteomics to quantify histone modifications (74-78) and screen post-translational modifications among enzymes involved in epigenetic processes, like DNMT and HDAC (79). Other approaches are required to identify specific DNA sequences paired with modified histones. In this regards, the ChIP assay is coupled with a genomic tiling array (ChIP-chip) or direct sequencing (ChIP-seq). In these techniques, DNA extracted from ChIP is further processed to reveal the whole sequence, allowing a detailed mapping of histone modifications affecting the whole genome (80).

\section{MIRNA - A BIOMARKER FOR OVARIAN CANCER?}

Regarding the diagnosis of ovarian cancer among unsuspecting patients, there is no early detection biomarker that is used during routine gynecological examinations of otherwise "healthy" individuals. Although there are many candidates and extensive ongoing research for biomarkers of early stage ovarian cancer, biomarkers like CA-125 and CEA are limited to management of confirmed cases. Since it is always desirable to detect malignancy in the early stages with a minimally invasive method to collect samples, the bar is set very high for this endeavor. In addition, the accuracy requirement of a biomarker in a rare malignancy like ovarian cancer is exceedingly challenging. 
In ovarian cancer, it is hypothesized that the detection of miRNAs present in circulation may be able to meet this challenge. The rationale for miRNAs as favored candidate biomarkers is due to the simplicity of obtaining blood samples and highsensitivity detection methods. In addition, miRNAs are found in circulation within protected exosomes, which are small vesicles released into the extracellular environment from many types of cells, including tumor cells $(81,82)$. Interestingly, the transfer of circulating miRNAs among cells is hypothesized to be a method for internal communication within the body, similar to hormones; thus, supporting the idea of a screening approach involving miRNAs $(82,83)$.

There are many examples from the literature supporting the concept of miRNA biomarkers for ovarian cancer. Studies show that the expression levels of eight miRNAs have prognostic value in ovarian cancer: miR-21, miR-141, miR-200a, miR-200b, miR-200c, miR-203, miR-205, and miR-214 (45). Another study identified the expression of 21 miRNAs significantly different between ovarian cancer and normal serum specimens, including three known oncogenic miRNAs (or "oncomirs") with biomarker potential: miR-21, miR-92, and miR-93 (84). Additionally, a large study using 300 plasma samples from ovarian cancer patients and 200 healthy controls evaluated circulating miRNAs and concluded that these are stable and specific. In this study, miR-205 and let-7f were significantly reduced in cancer specimens compared to normal controls. Moreover, let-7f has a lower expression level, which correlates with poor prognosis (85). Finally, another study suggests that among tumors, miR-9 and miR-223 deregulation is a biomarker of recurrent ovarian cancer (86).

Since miRNAs are released by cells into exosomes, studies have examined the viability of using exosomal miRNA as a potential biomarker. In this regard, research successfully used antiepithelial cell adhesion molecule (EpCAM) to isolate exosomes secreted from ovarian tumors in plasma and compared exosomecontaining miRNA expression profiles between samples from cancer patients versus healthy controls (87). Taylor and GercelTaylor intriguingly demonstrated that the level of tumor-derived circulating exosomes is higher in cancer patients than in normal controls. Furthermore, the level of increase correlates with higher disease grade when the exosomes are presented as concentrated protein. Finally, this study also showed that miRNAs profiles between cancer and benign specimens are significantly different (87). Because of the laboratory success in using these approaches, several groups have suggested the use of miRNAs and/or exosomes as surrogate or complementary biomarkers for biopsy profiling $(85,87,88)$.

\section{EPIGENETIC THERAPY IN OVARIAN CANCER EXPLOITING DNA METHYLATION FOR THERAPEUTIC MANAGEMENT Approaches to exploit DNA methylation changes for ovarian cancer therapy}

To reiterate, regions of the DNA experience changes in both hyperand hypo-methylation during cancer initiation and/or progression. In ovarian cancer, data suggest a correlation between global and satellite DNA hypo-methylation with malignancy since an overall increase in hypo-methylation is observed among ovarian cancer tissues, in comparison with normal controls $(89,90)$.
Furthermore, the phenomenon of satellite DNA hypo-methylation is an independent marker of poor prognosis (91).

Methylated genes are known in ovarian cancer and exhibit diagnostic potential. A study using methylation-specific PCR to screen ovarian tumor samples for six tumor suppressor genes (BRCA1, RASSF1A, APC, p14ARF, p16INK4a, and DAP-kinase) indicated that this "hyper-methylation panel" provides diagnostic information in ovarian cancer. In addition, this study further suggests that the panel is $82 \%$ sensitive and $100 \%$ specific for the detection of ovarian cancer using patient serum DNA in stage 1 (92).

The technology also holds potential use for ovarian cancerspecific prognostic information. For example, methylationspecific PCR analysis of tumor tissues from 270 patients identified that IGFBP-3 gene promoter hyper-methylation is associated with a higher risk of disease progression and mortality. Thus, hypermethylation of IGFBP-3 is hypothesized as a biomarker for ovarian cancer outcomes, especially for patients in early stages of the disease (93).

Due to the extensive aberrant DNA methylation in cancer and the reversible nature of these events, inhibition of DNMTs is a worthy therapeutic approach to re-express tumor suppressors. DNMTIs are categorized into nucleoside and non-nucleoside analogs based on their chemical structures and mechanisms of action. DNMT nucleoside inhibitors incorporate into DNA, trap and inactivate DNMTs in the form of a covalent-DNA adduct. On the other hand, non-nucleoside DNMTIs directly block DNMT activity without covalently trapping the enzyme, thus appearing to have less toxicity (94). 5,6-Dihydro-5-azacytidine (DHAC) is a nucleoside analog of DNMTI and is in clinical trials for the treatment of ovarian cancer (95). Hydralazine, a vasodilator that treats hypertension, is also a non-nucleoside DNMTI in clinical trials for cervical cancer as both monotherapy and combination therapy $(96,97)$.

\section{Pre-clinical studies and clinical trials exploiting DNA methylation for re-sensitization}

Ovarian cancer is a treatment-intensive disease and clinics are most often re-populated by their own patients. First-line chemotherapy is initially very effective in the treatment of ovarian cancer patients, but the period of remission they achieve is often shortlived. Thus, many approaches seek to re-sensitize tumors to the previously effective drugs. In contrast, others hypothesize that because previous attempts to re-sensitize recurrent ovarian tumors to first-line therapeutics has failed, they suggest that initial combinations of compounds aimed at preventing chemoresistance is the best approach (98). However, since neither approach has achieved bona-fide, proof-of-principle, research into both approaches is ongoing.

Researchers are evaluating the application of DNA methylation for chemotherapy re-sensitization. For example, the hypermethylation of hMLH1 (human MutL homolog 1) inhibits the apoptotic response to platinum-DNA abduct formation from platinum chemotherapy. Thus, this hyper-methylation is considered a major molecular cause of acquired resistance to platinum chemotherapy in ovarian cancer (99). In addition, the presence of methylated hMLH1 DNA in plasma after chemotherapy predicts poor survival for ovarian cancer patients (100). Interestingly, 
the hMLH1 activity is restored after treatment with 5-aza- $2^{\prime}$ deoxycytidine (decitabine) and so is the re-sensitization of ovarian cancer to cisplatin (101).

Another example of DNA methylation and chemotherapy resensitization surrounds RAS-associated domain family protein 1a (RASSF1A). The promoter methylation of RASSF1A is highly associated with ovarian cancer (34). RASSF1A binds to tubulin and promotes microtubule polymerization and stabilization (102, 103). The presence of RASSF1A blocks genome instability induced by RAS $(85,104)$. RASSF1A also causes cell cycle arrest through blocking Cyclin D1 accumulation (105). For all these reasons, RASSF1A is an interesting target for restoration.

Many pre-clinical studies present evidence that DNMT inhibitors are efficient in de-repressing tumor suppressor genes. This intimates that DNMT inhibitors may have therapeutic potential in combination regimens to overcome resistance and/or provide synergistic effects $(106,107)$. For example, decitabine resensitizes chemoresistant ovarian tumor xenografts to cisplatin, carboplatin, temozolomide, and epirubicin (101). Restoration of RASFF1A by inhibiting DNMT also increases ovarian cancer cell sensitivity to paclitaxel (108).

Indeed, DNMT inhibitors are also showing some success in the clinic (Table 2). Decitabine is undergoing clinical trials with carboplatin for patients with recurrent, platinum-resistant ovarian cancer (109). A report of a phase II clinical trial of low-dose decitabine combined with carboplatin for heavily treated and platinum-resistant ovarian cancer patients showed positive results. Low-dose decitabine altered the methylation of genes in tumorigenesis pathways, including the demethylation of hMLH1, RASSF1A, HOXA10, and HOXA11, leading to re-sensitization to carboplatin, increased response rate, and prolonged progression-free survival (110).

Hypo-methylation treatment, on the other hand, due to its non-specific effects, can be detrimental. One known example is the Fanconi anemia (FANC)-BRCA pathway in ovarian cancer. The malfunction of genes in FANC pathway leads to devastating mutagen hypersensitivity (111). In cancer treatment, the FNACBRCA pathway plays a critical role in the response of cells to DNA-crosslinking agents. However, it was observed that, in ovarian cancer, FANC is inactivated due to hyper-methylation, and the demethylation of FANC is associated with ovarian tumor progression and acquired cisplatin resistance (112). In addition, there are oncogenic genes overexpressed by hypo-methylation in ovarian cancer, such as synuclein- $\gamma$ and mammalian heparanase (endo-beta-glucuronidase) (113-115).

Table 2 | Epigenetic drugs in gynecological cancer trials.

\begin{tabular}{|c|c|c|c|}
\hline Drugs & Other names & Group & Types of diseases \\
\hline Valproic acid & & HDAC inhibitors & Cervical, ovarian cancers \\
\hline Belinostat & & HDAC inhibitors & Gynecological cancers \\
\hline Decitabine & & DNMT inhibitors & Ovarian cancer \\
\hline Hydralazine & & DNMT inhibitors & Cervical cancer \\
\hline $\begin{array}{l}\text { Dihydro-5- } \\
\text { azacytidine }\end{array}$ & DHAC & DNMT inhibitors & Ovarian cancer \\
\hline
\end{tabular}

\section{HISTONE MODIFICATIONS: HISTONE DEACETYLASE INHIBITION IN CLINICAL TRIALS}

Histone deacetylases are enzymes that remove acetyl groups and have long been studied for treatment of cancer, in general, as well as of gynecological cancers, specifically. Although HDAC overexpression occurs in many types of cancers $(116,117)$, siRNA silencing HDAC1 and HDAC2 inhibits growth and promotes apoptosis in ovarian and cervical cancer cells $(118,119)$. Similarly, HDAC6 facilitates oncogenic transformation in ovarian cancer (120). Thus, there is sufficient support for the rational targeting and inhibiting HDAC within the treatment of this malignancy.

Based on their chemical structures, HDAC inhibitors are divided into four majors groups: short-chain fatty acid, hydroxamic acid, cyclic tetrapeptide, and benzamide (121). For example, valproic acid, a reagent belonging to the short-chain fatty acid group (also known as an anti-epileptic and mood stabilizer) is in clinical trials for the treatment of cervical and ovarian cancers (122-124). Scriptaid, another HDAC inhibitor in the hydroxamic group, showed growth inhibition and apoptosis-inducing potential in ovarian and endometrial cancers (125). Apicidin, an HDAC inhibitor in the cyclic tetrapeptide group, is also studied for its anti-growth effects in ovarian and endometrial cancer cells (126).

The aberrant expression of HDACs in gynecological cancers is likely associated with de novo resistance and/or poor chemotherapeutic efficacy and thus, chemoresistance development. As with nearly all new drugs, HDAC inhibitors are proposed for combination therapy to strengthen therapeutic efficacy as well as to minimize chemoresistance. Valproic acid has been studied in combination with several cytotoxic drugs, such as methotrexate or epirubicin, for synergistic or antagonistic effects in other types of cancer $(127,128)$. Belinostat (PDX101), a novel HDAC inhibitor in the hydroxamic acid group, displayed anticancer effects as a single agent as well as in combination by increasing the acetylation of tubulin induced by docetaxel and the phosphorylation of H2AX induced by carboplatin (129). Belinostat is under phase II clinical trials for gynecological cancer treatment in combination with platinum or paclitaxel to enhance effectiveness and help overcome resistance (130-134). OSU-HDAC42 (or AR-42), another new short-chain fatty acid HDAC inhibitor, has anti-growth effects on ovarian cancer cells but not normal epithelial cells. The compound re-sensitizes platinum-resisted ovarian tumors in vivo to cisplatin and may have great potential for combinations with platinum agents (135).

\section{EXPLOITING mIRNAs FOR RE-SENSITIZATION OF CHEMORESISTANT DISEASE}

The goal of targeting miRNAs in cancer treatment is to downregulate oncomirs, to inhibit mRNAs that will become oncogenic proteins, or to restore tumor suppressor miRNAs. Multiple techniques have been developed to target oncomirs, such as locked nucleic acid (LNA), miRNA sponges, miRNA masking, or small-molecule inhibitors (136-139). On the other hand, the most straightforward way to restore tumor suppressor miRNAs is to deliver pre-miRNA precursors or miRNA mimics. However, straightforward it may appear, it is the targeted delivery of these molecules that represents a major obstacle. 
A critical clinical problem in ovarian cancer is chemoresistance. Multiple studies in the field have focused on the roles of miRNAs in overcoming resistance to chemotherapeutic agents. Many miRNAs are reported as expressed differently between chemosensitive and chemoresistant ovarian cell lines, such as miR-30c, miR-130a, miR-335, among those, miR-130a is confirmed to target resistant factor M-CSF (Table 3) (140). In addition, the enforced expression of miR-30c-2-3p into chemoresistant and chemo-insensitive ovarian cancer cells significantly reduces their viability, independently of cisplatin or paclitaxel, without affecting immortalized ovarian surface epithelial cells (141).

Although the miR-200 family is a potential prognostic factor of ovarian and endometrial cancer $(87,155)$, it may have a role in re-sensitization. The low expression of miR-200c in cancer leads to an increase in the expression of its target, class III $\beta$-tubulin (TUBB3) (142). Since the expression of TUBB3 is required for chemoresistance to microtubule-binding agents (e.g., taxanes and vinca alkaloids), restoration of miR-200c downregulates TUBB3, and effectively re-sensitizes ovarian cancer cells to paclitaxel $(142,143,156)$.

In addition to the miR-200 family, several members of the let-7 family are well documented as down-regulated in ovarian cancer, including let-7a, let-7b, let-7c, let-7d, and let-7i (4448, 144). Among these, let-7a is a potential biomarker for the selection of chemotherapy in ovarian cancer. Patients with low let-7 showed good response using platinum-paclitaxel combination therapy, while patients with higher let-7a had better survival using platinum without paclitaxel; adding paclitaxel to this group produced worse progression-free and overall survival (147). The down-regulation of another member of the let-7 family, let-7i, is associated with resistance of ovarian cancer cells to cisplatin, which suggests that let-7i could be used as a therapeutic target to overcome platinum resistance and as a biomarker to predict chemotherapy response in ovarian cancer patients (144). Another study observed that the let-7 family member, let-7g, downregulates the multiple drug resistance 1 (MDR1) gene, one of the major factors causing paclitaxel resistance in ovarian cancer (145).

There are numerous other miRNAs that have roles in ovarian cancer chemoresistance with known mechanisms. These include, but are not limited to, miRNAs like miR-214, miR-27a, and miR451. MiR-214 targets PTEN, a known tumor suppressor, therefore, inducing cell survival and cisplatin resistance (46). MiR-27a increases MDR1/P-glycoprotein expression in ovarian cancer cells by targeting HIPK2 as an intermediate (157). Similarly, miR-451 and miR-21 also facilitate MDR1/P-glycoprotein overexpression, leading to paclitaxel resistance in ovarian cancer cells $(158,159)$.

\section{TARGETING TRANSCRIPTION FACTORS IN OVARIAN CANCER}

Cancer is often a condition with aberrant gene expression, specifically involving the overexpression of oncogenes. Altered transcription factors are recognized as an epigenetic entity comprising the "ovarian cancer cell epigenome" (3). This is not surprising given the relationship between transcription factors and structural (not sequence) alterations of the DNA (via DNA methylation and histone modifications).

There are numerous examples of aberrant transcription factors in cancer. Perhaps the most prominent of all is the tumor suppressor protein p53. Mutations of TP53, the gene encoding p53, are very common in ovarian cancer (160). In fact, nearly $100 \%$ of patients with high-grade serous epithelial ovarian cancer have

Table 3 | miRNAs involved in chemoresistance.

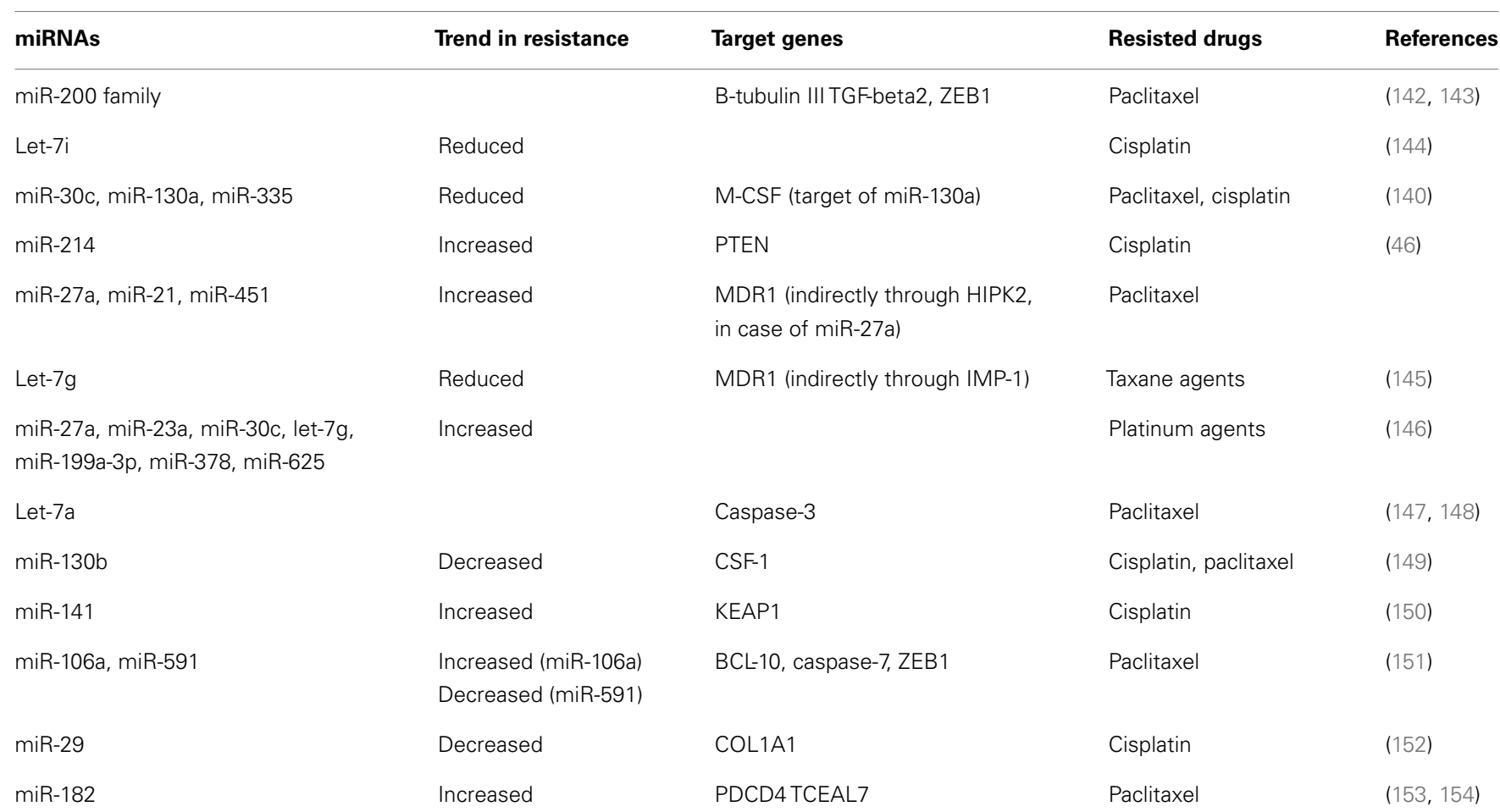


mutations in p53. Overall, at least 50\% of all ovarian tumors have mutations in p53, most of which are point mutations leading to amino acid substitutions. These are detrimental to the $\mathrm{p} 53$ protein because they affect the DNA-binding domain of the transcription factor (161). Unfortunately, therapeutic intervention using p53 as the target molecule has not yet achieved measurable success (98).

The transcription factor and tumor suppressor protein p53 are critical to the signaling pathways of cell cycle arrest and apoptosis. Once activated by DNA damage detection or UV radiation, p53 induces the expression of many well-known apoptosis inducers and other tumor suppressors, such as $\mathrm{p} 21^{\mathrm{Cip} 1}$, BAX, PTEN, and TSP-1. Because of this important role, the inactivation of p53 facilitates many phases of tumor progression as DNA damage cannot be repaired and apoptotic pathways cannot be activated when necessary (161).

Beside p53, other transcription factors have important roles in ovarian cancer pathology. For example, Gill (glioma-associated oncogene homolog 1) expression is elevated in advanced serous ovarian cancer and this event is correlated with unfavorable survival (162). Since transcription factor alterations can have a tremendous impact on the balance of the entire biological system, targeting transcription factors is an emerging trend in cancer therapy research. The possibility of exerting broad control over the system could be a powerful method of regaining regulatory control. This is especially in light of lessons learned in other cancers whereby targeting one particular kinase or protein in a larger signaling pathway leads to the rapid acquisition of therapeutic resistance.

On the other hand, inhibiting particular transcription factors could provide specificity toward malignant overexpression events in cancer (e.g., oncogenes, oncomirs, etc.). Furthermore, this approach is appealing because it might produce more tolerance among healthy cells due to redundancies in normal signaling pathways. Two major approaches in targeting transcription factors are post-transcriptional silencing (using siRNAs or miRNAs) or blocking the binding of transcription factors to DNA during activation. Another indirect approach is regulating histone-modified enzymes and DNA methyltransferase if the target transcription factor is mis-regulated through histone modification and/or DNA methylation.

Many well-known transcription factors are studied as potential targets in general cancer treatment, such as STATs, NF-кB, and Notch1 (163-165). In gynecological cancers, multiple studies have reported the involvement of transcription factors in cancer progression and described them as potential targets for cancer treatment. In ovarian cancer, the blockage of STAT3 using a decoy oligodeoxynucleotide inhibits cancer cell growth (166). Another study in ovarian cancer also showed that suppression of NF- $\kappa$ B activity using minocycline, a tetracycline, had beneficial effects both in vitro and in vivo (167). More research is needed in this area to refine this approach and evaluate its worthiness.

\section{CONCLUSION: EPIGENETIC THERAPY}

By undertaking research projects focused on epigenetic-related translational applications, are basic scientists investigating a rational clinical promise? To address this question, it is necessary to review the successful progression of ideas from the laboratory into clinic therapeutics. Although no epigenetic drugs have advanced into the clinic for use against ovarian cancer, there are several FDA-approved therapeutics (e.g., vorinostat, decitabine, and romidepsin) for other types of cancer, especially liquid tumors. Clinical trials are ongoing for ovarian cancer with epigenetic therapeutics (Table 2). Since first-line therapy often results in disease remission, predictions support using new drugs in combination therapy. Although hope lingers for PARP inhibitors, this class of drugs may only treat a specific population of women (168). Whether using epigenetic modifiers will achieve significant improvements in overall survival is incalculable. Nevertheless, to advance patient outcomes in ovarian cancer, new approaches are required - the previous breakthroughs occurred in 1978 (cisplatin) and 1992 (paclitaxel). An improved therapeutic regimen for ovarian cancer is long overdue. Epigenetics provide hope in a new direction.

\section{ACKNOWLEDGMENTS}

This work was supported by research grants from the National Institutes of Health (1R15CA151006-01 American Recovery and Reinvestment Act and 1R15CA176653-01A1), a Research Scholar Grant 120634-RSG-11-269-01-CDD from the American Cancer Society and a Distinguished Scientist award from the Georgia Research Alliance, all to Mandi M. Murph. Geng Tian is supported by an award from the China Scholarship Council.

\section{REFERENCES}

1. Goldberg AD, Allis CD, Bernstein E. Epigenetics: a landscape takes shape. Cell (2007) 128(4):635-8. doi:10.1016/j.cell.2007.02.006

2. Bird A. Perceptions of epigenetics. Nature (2007) 447(7143):396-8. doi:10. 1038/nature05913

3. Balch C, Fang F, Matei DE, Huang TH, Nephew KP. Minireview: epigenetic changes in ovarian cancer. Endocrinology (2009) 150(9):4003-11. doi:10.1210/ en.2009-0404

4. Iacobuzio-Donahue CA. Epigenetic changes in cancer. Annu Rev Pathol Mech Dis (2009) 4:229-49. doi:10.1146/annurev.pathol.3.121806.151442

5. Robertson KD, Jones PA. DNA methylation: past, present and future directions. Carcinogenesis (2000) 21(3):461-7. doi:10.1093/carcin/21.3.461

6. Zhu X, Lee K, Asa SL, Ezzat S. Epigenetic silencing through DNA and histone methylation of fibroblast growth factor receptor 2 in neoplastic pituitary cells. Am J Pathol (2007) 170(5):1618-28. doi:10.2353/ajpath.2007.061111

7. Bestor TH. The host defence function of genomic methylation patterns. Novartis Found Symp (1998) 214:187-95; discussion 195-9, 228-32. doi:10.1002/ 9780470515501.ch11

8. Rodriguez-Paredes M, Esteller M. Cancer epigenetics reaches mainstream oncology. Nat Med (2011) 17(3):330-9. doi:10.1038/nm.2305

9. Alves G, Tatro A, Fanning T. Differential methylation of human LINE-1 retrotransposons in malignant cells. Gene (1996) 176(1-2):39-44. doi:10.1016/ 0378-1119(96)00205-3

10. Costello JF, Plass C. Methylation matters. J Med Genet (2001) 38(5):285-303. doi:10.1136/jmg.38.5.285

11. Eden A, Gaudet F, Waghmare A, Jaenisch R. Chromosomal instability and tumors promoted by DNA hypomethylation. Science (2003) 300(5618):455. doi:10.1126/science.1083557

12. Gaudet F, Hodgson JG, Eden A, Jackson-Grusby L, Dausman J, Gray JW, et al. Induction of tumors in mice by genomic hypomethylation. Science (2003) 300(5618):489-92. doi:10.1126/science.1083558

13. Tuck-Muller CM, Narayan A, Tsien F, Smeets DF, Sawyer J, Fiala ES, et al. DNA hypomethylation and unusual chromosome instability in cell lines from ICF syndrome patients. Cytogenet Cell Genet (2000) 89(1-2):121-8. doi:10.1159/000015590

14. Kanai Y. Genome-wide DNA methylation profiles in precancerous conditions and cancers. Cancer Sci (2010) 101(1):36-45. doi:10.1111/j.1349-7006.2009. 01383.x 
15. Esteller M. Cancer epigenomics: DNA methylomes and histone-modification maps. Nat Rev Genet (2007) 8(4):286-98. doi:10.1038/nrg2005

16. Kouzarides T. Chromatin modifications and their function. Cell (2007) 128(4):693-705. doi:10.1016/j.cell.2007.02.005

17. Fischle W, Wang Y, Allis CD. Histone and chromatin cross-talk. Curr Opin Cell Biol (2003) 15(2):172-83. doi:10.1016/S0955-0674(03)00013-9

18. Roth SY, Denu JM, Allis CD. Histone acetyltransferases. Annu Rev Biochem (2001) 70:81-120. doi:10.1146/annurev.biochem.70.1.81

19. Thiagalingam S, Cheng KH, Lee HJ, Mineva N, Thiagalingam A, Ponte JF. Histone deacetylases: unique players in shaping the epigenetic histone code. Ann N Y Acad Sci (2003) 983:84-100. doi:10.1111/j.1749-6632.2003.tb05964.x

20. Beisel C, Imhof A, Greene J, Kremmer E, Sauer F. Histone methylation by the Drosophila epigenetic transcriptional regulator Ash1. Nature (2002) 419(6909):857-62. doi:10.1038/nature01126

21. Cheung P, Allis CD, Sassone-Corsi P. Signaling to chromatin through histone modifications. Cell (2000) 103(2):263-71. doi:10.1016/S00928674(00)00118-5

22. Fuks F. DNA methylation and histone modifications: teaming up to silence genes. Curr Opin Genet Dev (2005) 15(5):490-5. doi:10.1016/j.gde.2005.08.002

23. Simon JA, Lange CA. Roles of the EZH2 histone methyltransferase in cancer epigenetics. Mutat Res (2008) 647(1-2):21-9. doi:10.1016/j.mrfmmm.2008. 07.010

24. Vaissiere T, Sawan C, Herceg Z. Epigenetic interplay between histone modifications and DNA methylation in gene silencing. Mutat Res (2008) 659(1-2):40-8. doi:10.1016/j.mrrev.2008.02.004

25. Baek D, Villén J, Shin C, Camargo FD, Gygi SP, Bartel DP. The impact of microRNAs on protein output. Nature (2008) 455(7209):64-71. doi:10.1038/ nature07242

26. Bartel DP. MicroRNAs: genomics, biogenesis, mechanism, and function. Cell (2004) 116(2):281-97. doi:10.1016/S0092-8674(04)00045-5

27. Calin GA, Croce CM. MicroRNA signatures in human cancers. Nat Rev Cancer (2006) 6(11):857-66. doi:10.1038/nrc1997

28. Lu J, Getz G, Miska EA, Alvarez-Saavedra E, Lamb J, Peck D, et al. MicroRNA expression profiles classify human cancers. Nature (2005) 435(7043):834-8. doi:10.1038/nature03702

29. Esquela-Kerscher A, Slack FJ. Oncomirs - microRNAs with a role in cancer. Nat Rev Cancer (2006) 6(4):259-69. doi:10.1038/nrc1840

30. Bi FF, Li D, Cao C, Li CY, Yang Q. Regulation of angiotensin II type 1 receptor expression in ovarian cancer: a potential role for BRCA1. J Ovarian Res (2013) 6(1):89. doi:10.1186/1757-2215-6-89

31. Meng CF, Su B, Li W. DNA demethylation is superior to histone acetylation for reactivating cancer-associated genes in ovarian cancer cells. Mol Med Rep (2011) 4(6):1273-8. doi:10.3892/mmr.2011.557

32. Ferrone CR, Levine DA, Tang LH, Allen PJ, Jarnagin W, Brennan MF, et al. BRCA germline mutations in Jewish patients with pancreatic adenocarcinoma. J Clin Oncol (2009) 27(3):433-8. doi:10.1200/JCO.2008.18.5546

33. Matsumura N, Huang Z, Mori S, Baba T, Fujii S, Konishi I, et al. Epigenetic suppression of the TGF-beta pathway revealed by transcriptome profiling in ovarian cancer. Genome Res (2011) 21(1):74-82. doi:10.1101/gr. 108803.110

34. Shi H, Li Y, Wang X, Lu C, Yang L, Gu C, et al. Association between RASSF1A promoter methylation and ovarian cancer: a meta-analysis. PLoS One (2013) 8(10):e76787. doi:10.1371/journal.pone.0076787

35. Abdollahi A, Pisarcik D, Roberts D, Weinstein J, Cairns P, Hamilton TC. LOT1 (PLAGL1/ZAC1), the candidate tumor suppressor gene at chromosome 6q2425, is epigenetically regulated in cancer. J Biol Chem (2003) 278(8):6041-9. doi:10.1074/jbc.M210361200

36. Collins Y, Dicioccio R, Keitz B, Lele S, Odunsi K. Methylation of deathassociated protein kinase in ovarian carcinomas. Int J Gynecol Cancer (2006) 16(Suppl 1):195-9. doi:10.1111/j.1525-1438.2006.00506.x

37. Terasawa K, Sagae S, Toyota M, Tsukada K, Ogi K, Satoh A, et al. Epigenetic inactivation of TMS1/ASC in ovarian cancer. Clin Cancer Res (2004) 10(6):2000-6. doi:10.1158/1078-0432.CCR-0932-03

38. Torng PL, Lin CW, Chan MW, Yang HW, Huang SC, Lin CT. Promoter methylation of IGFBP-3 and p53 expression in ovarian endometrioid carcinoma. $\mathrm{Mol}$ Cancer (2009) 8:120. doi:10.1186/1476-4598-8-120

39. Kwon MJ, Kim SS, Choi YL, Jung HS, Balch C, Kim SH, et al. Derepression of CLDN3 and CLDN4 during ovarian tumorigenesis is associated with loss of repressive histone modifications. Carcinogenesis (2010) 31(6):974-83. doi:10.1093/carcin/bgp336

40. Murph MM, Liu W, Yu S, Lu Y, Hall H, Hennessy BT, et al. Lysophosphatidic acid-induced transcriptional profile represents serous epithelial ovarian carcinoma and worsened prognosis. PLoS One (2009) 4(5):e5583. doi:10.1371/ journal.pone.0005583

41. Chan MW, Huang YW, Hartman-Frey C, Kuo CT, Deatherage D, Qin H, et al. Aberrant transforming growth factor betal signaling and SMAD4 nuclear translocation confer epigenetic repression of ADAM19 in ovarian cancer. Neoplasia (2008) 10(9):908-19. doi:10.1593/neo.08540

42. Zhang L, Huang J, Yang N, Greshock J, Megraw MS, Giannakakis A, et al. microRNAs exhibit high frequency genomic alterations in human cancer. Proc Natl Acad Sci U S A (2006) 103(24):9136-41. doi:10.1073/pnas.0508889103

43. Gilabert-Estelles J, Braza-Boils A, Ramon LA, Zorio E, Medina P, Espana F, et al. Role of microRNAs in gynecological pathology. Curr Med Chem (2012) 19(15):2406-13. doi:10.2174/092986712800269362

44. Zhang L, Volinia S, Bonome T, Calin GA, Greshock J, Yang N, et al. Genomic and epigenetic alterations deregulate microRNA expression in human epithelial ovarian cancer. Proc Natl Acad Sci U S A (2008) 105(19):7004-9. doi:10. 1073/pnas.0801615105

45. Iorio MV, Visone R, Di Leva G, Donati V, Petrocca F, Casalini P, et al. MicroRNA signatures in human ovarian cancer. Cancer Res (2007) 67(18):8699-707. doi:10.1158/0008-5472.CAN-07-1936

46. Yang H, Kong W, He L, Zhao JJ, O’Donnell JD, Wang J, et al. MicroRNA expression profiling in human ovarian cancer: miR-214 induces cell survival and cisplatin resistance by targeting PTEN. Cancer Res (2008) 68(2):425-33. doi:10.1158/0008-5472.CAN-07-2488

47. Nam EJ, Yoon H, Kim SW, Kim H, Kim YT, Kim JH, et al. MicroRNA expression profiles in serous ovarian carcinoma. Clin Cancer Res (2008) 14(9):2690-5. doi:10.1158/1078-0432.CCR-07-1731

48. Dahiya N, Sherman-Baust CA, Wang TL, Davidson B, Shih IEM, Zhang Y, et al. MicroRNA expression and identification of putative miRNA targets in ovarian cancer. PLoS One (2008) 3(6):e2436. doi:10.1371/journal.pone.0002436

49. Merritt WM, Lin YG, Han LY, Kamat AA, Spannuth WA, Schmandt R, et al. Dicer, Drosha, and outcomes in patients with ovarian cancer. $N$ Engl J Med (2008) 359(25):2641-50. doi:10.1056/NEJMoa0803785

50. Kumar MS, Pester RE, Chen CY, Lane K, Chin C, Lu J, et al. Dicer1 functions as a haploinsufficient tumor suppressor. Genes Dev (2009) 23(23):2700-4. doi:10.1101/gad.1848209

51. Lu L, Katsaros D, de laLongrais IA, Sochirca O, Yu H. Hypermethylation of let-7a-3 in epithelial ovarian cancer is associated with low insulinlike growth factor-II expression and favorable prognosis. Cancer Res (2007) 67(21):10117-22. doi:10.1158/0008-5472.CAN-07-2544

52. Friedman JM, Liang G, Liu CC, Wolff EM, Tsai YC, Ye W, et al. The putative tumor suppressor microRNA-101 modulates the cancer epigenome by repressing the polycomb group protein EZH2. Cancer Res (2009) 69(6):2623-9. doi:10.1158/0008-5472.CAN-08-3114

53. Iorio MV, Piovan C, Croce CM. Interplay between microRNAs and the epigenetic machinery: an intricate network. Biochim Biophys Acta (2010) 1799(1012):694-701. doi:10.1016/j.bbagrm.2010.05.005

54. Tuddenham L, Wheeler G, Ntounia-Fousara S, Waters J, Hajihosseini MK, Clark I, et al. The cartilage specific microRNA-140 targets histone deacetylase 4 in mouse cells. FEBS Lett (2006) 580(17):4214-7. doi:10.1016/j.febslet.2006. 06.080

55. Esteller M. Epigenetics in cancer. N Engl J Med (2008) 358(11):1148-59. doi:10.1056/NEJMra072067

56. Ushijima T, Morimura K, Hosoya Y, Okonogi H, Tatematsu M, Sugimura $\mathrm{T}$, et al. Establishment of methylation-sensitive-representational difference analysis and isolation of hypo- and hypermethylated genomic fragments in mouse liver tumors. Proc Natl Acad Sci U S A (1997) 94(6):2284-9. doi:10.1073/pnas.94.6.2284

57. Weber M, Davies JJ, Wittig D, Oakeley EJ, Haase M, Lam WL, et al. Chromosome-wide and promoter-specific analyses identify sites of differential DNA methylation in normal and transformed human cells. Nat Genet (2005) 37(8):853-62. doi:10.1038/ng1598

58. Wilson IM, Davies JJ, Weber M, Brown CJ, Alvarez CE, MacAulay C, et al. Epigenomics: mapping the methylome. Cell Cycle (2006) 5(2):155-8. doi:10. 4161/cc.5.2.2367 
59. Herman JG, Graff JR, Myöhänen S, Nelkin BD, Baylin SB. Methylation-specific PCR: a novel PCR assay for methylation status of CpG islands. Proc Natl Acad Sci U S A (1996) 93(18):9821-6. doi:10.1073/pnas.93.18.9821

60. Yang HJ, Liu VW, Wang Y, Tsang PC, Ngan HY. Differential DNA methylation profiles in gynecological cancers and correlation with clinico-pathological data. BMC Cancer (2006) 6:212. doi:10.1186/1471-2407-6-212

61. Hodges E, Xuan Z, Balija V, Kramer M, Molla MN, Smith SW, et al. Genomewide in situ exon capture for selective resequencing. Nat Genet (2007) 39(12):1522-7. doi:10.1038/ng.2007.42

62. Porreca GJ, Zhang K, Li JB, Xie B, Austin D, Vassallo SL, et al. Multiplex amplification of large sets of human exons. Nat Methods (2007) 4(11):931-6. doi:10.1038/nmeth1110

63. Lee EJ, Pei L, Srivastava G, Joshi T, Kushwaha G, Choi JH, et al. Targeted bisulfite sequencing by solution hybrid selection and massively parallel sequencing. Nucleic Acids Res (2011) 39(19):e127. doi:10.1093/nar/gkr598

64. Hodges E, Smith AD, Kendall J, Xuan Z, Ravi K, Rooks M, et al. High definition profiling of mammalian DNA methylation by array capture and single molecule bisulfite sequencing. Genome Res (2009) 19(9):1593-605. doi:10.1101/gr.095190.109

65. Varley KE, Mitra RD. Bisulfite patch PCR enables multiplexed sequencing of promoter methylation across cancer samples. Genome Res (2010) 20(9):1279-87. doi:10.1101/gr.101212.109

66. Lee EJ, Luo J, Wilson JM, Shi H. Analyzing the cancer methylome through targeted bisulfite sequencing. Cancer Lett (2013) 340(2):171-8. doi:10.1016/j. canlet.2012.10.040

67. Shanmuganathan R, Basheer NB, Amirthalingam L, Muthukumar H, Kaliaperumal R, Shanmugam K. Conventional and nanotechniques for DNA methylation profiling. J Mol Diagn (2013) 15(1):17-26. doi:10.1016/j.jmoldx.2012. 06.007

68. Brinkman AB, Simmer F, Ma K, Kaan A, Zhu J, Stunnenberg HG. Wholegenome DNA methylation profiling using MethylCap-seq. Methods (2010) 52(3):232-6. doi:10.1016/j.ymeth.2010.06.012

69. Huang RL, Gu F, Kirma NB, Ruan J, Chen CL, Wang HC, et al. Comprehensive methylome analysis of ovarian tumors reveals hedgehog signaling pathway regulators as prognostic DNA methylation biomarkers. Epigenetics (2013) 8(6):624-34. doi:10.4161/epi.24816

70. Wei Y, Xia W, Zhang Z, Liu J, Wang H, Adsay NV, et al. Loss of trimethylation at lysine 27 of histone $\mathrm{H} 3$ is a predictor of poor outcome in breast, ovarian, and pancreatic cancers. Mol Carcinog (2008) 47(9):701-6. doi:10.1002/mc. 20413

71. Maloney A, Clarke PA, Naaby-Hansen S, Stein R, Koopman JO, Akpan A, et al. Gene and protein expression profiling of human ovarian cancer cells treated with the heat shock protein 90 inhibitor 17-allylamino17-demethoxygeldanamycin. Cancer Res (2007) 67(7):3239-53. doi:10.1158/ 0008-5472.CAN-06-2968

72. Ali MW, Cacan E, Liu Y, Pierce JY, Creasman WT, Murph MM, et al. Transcriptional suppression, DNA methylation, and histone deacetylation of the regulator of G-protein signaling 10 (RGS10) gene in ovarian cancer cells. PLoS One (2013) 8(3):e60185. doi:10.1371/journal.pone.0060185

73. Hooks SB, Callihan P, Altman MK, Hurst JH, Ali MW, Murph MM. Regulators of G-Protein signaling RGS10 and RGS17 regulate chemoresistance in ovarian cancer cells. Mol Cancer (2010) 9:289. doi:10.1186/1476-4598-9-289

74. Bonenfant D, Towbin H, Coulot M, Schindler P, Mueller DR, van Oostrum J. Analysis of dynamic changes in post-translational modifications of human histones during cell cycle by mass spectrometry. Mol Cell Proteomics (2007) 6(11):1917-32. doi:10.1074/mcp.M700070-MCP200

75. Garcia BA, Mollah S, Ueberheide BM, Busby SA, Muratore TL, Shabanowitz J, et al. Chemical derivatization of histones for facilitated analysis by mass spectrometry. Nat Protoc (2007) 2(4):933-8. doi:10.1038/nprot.2007.106

76. Plazas-Mayorca MD, Zee BM, Young NL, Fingerman IM, LeRoy G, Briggs SD, et al. One-pot shotgun quantitative mass spectrometry characterization of histones. J Proteome Res (2009) 8(11):5367-74. doi:10.1021/pr900777e

77. Sweet SM, Li M, Thomas PM, Durbin KR, Kelleher NL. Kinetics of reestablishing H3K79 methylation marks in global human chromatin. J Biol Chem (2010) 285(43):32778-86. doi:10.1074/jbc.M110.145094

78. Zee BM, Levin RS, Xu B, LeRoy G, Wingreen NS, Garcia BA. In vivo residuespecific histone methylation dynamics. J Biol Chem (2010) 285(5):3341-50. doi:10.1074/jbc.M109.063784
79. Bartke T, Borgel J, DiMaggio PA. Proteomics in epigenetics: new perspectives for cancer research. Brief Funct Genomics (2013) 12(3):205-18. doi:10.1093/ bfgp/elt002

80. Ho JW, Bishop E, Karchenko PV, Nègre N, White KP, Park PJ. ChIP-chip versus ChIP-seq: lessons for experimental design and data analysis. BMC Genomics (2011) 12:134. doi:10.1186/1471-2164-12-134

81. Lakkaraju A, Rodriguez-Boulan E. Itinerant exosomes: emerging roles in cell and tissue polarity. Trends Cell Biol (2008) 18(5):199-209. doi:10.1016/j.tcb. 2008.03.002

82. Wittmann J, Jack HM. Serum microRNAs as powerful cancer biomarkers. Biochim Biophys Acta (2010) 1806(2):200-7. doi:10.1016/j.bbcan.2010.07.002

83. Benner SA. Extracellular 'communicator RNA.' FEBS Lett (1988) 233(2):225-8. doi:10.1016/0014-5793(88)80431-9

84. Resnick KE, Alder H, Hagan JP, Richardson DL, Croce CM, Cohn DE. The detection of differentially expressed microRNAs from the serum of ovarian cancer patients using a novel real-time PCR platform. Gynecol Oncol (2009) 112(1):55-9. doi:10.1016/j.ygyno.2008.08.036

85. Zheng H, Zhang L, Zhao Y, Yang D, Song F, Wen Y, et al. Plasma miRNAs as diagnostic and prognostic biomarkers for ovarian cancer. PLoS One (2013) 8(11):e77853. doi:10.1371/journal.pone.0077853

86. Laios A, O’Toole S, Flavin R, Martin C, Kelly L, Ring M, et al. Potential role of miR-9 and miR-223 in recurrent ovarian cancer. Mol Cancer (2008) 7:35. doi:10.1186/1476-4598-7-35

87. Taylor DD, Gercel-Taylor C. MicroRNA signatures of tumor-derived exosomes as diagnostic biomarkers of ovarian cancer. Gynecol Oncol (2008) 110(1):13-21. doi:10.1016/j.ygyno.2008.04.033

88. Jacobs IJ, Menon U. Progress and challenges in screening for early detection of ovarian cancer. Mol Cell Proteomics (2004) 3(4):355-66. doi:10.1074/mcp. R400006-MCP200

89. Qu G, Dubeau L, Narayan A, Yu MC, Ehrlich M. Satellite DNA hypomethylation vs. overall genomic hypomethylation in ovarian epithelial tumors of different malignant potential. Mutat Res (1999) 423(1-2):91-101. doi:10.1016/S00275107(98)00229-2

90. Ehrlich M, Woods CB, Yu MC, Dubeau L, Yang F, Campan M, et al. Quantitative analysis of associations between DNA hypermethylation, hypomethylation, and DNMT RNA levels in ovarian tumors. Oncogene (2006) 25(18):2636-45. doi:10.1038/sj.onc. 1209145

91. Widschwendter M, Jiang G, Woods C, Müller HM, Fiegl H, Goebel G, et al. DNA hypomethylation and ovarian cancer biology. Cancer Res (2004) 64(13):4472-80. doi:10.1158/0008-5472.CAN-04-0238

92. Ibanez de Caceres I, Battagli C, Esteller M, Herman JG, Dulaimi E, Edelson MI, et al. Tumor cell-specific BRCA1 and RASSF1A hypermethylation in serum, plasma, and peritoneal fluid from ovarian cancer patients. Cancer Res (2004) 64(18):6476-81. doi:10.1158/0008-5472.CAN-04-1529

93. Wiley A, Katsaros D, Fracchioli S, Yu H. Methylation of the insulin-like growth factor binding protein-3 gene and prognosis of epithelial ovarian cancer. Int J Gynecol Cancer (2006) 16(1):210-8. doi:10.1111/j.1525-1438.2006.00299.x

94. Lyko F, Brown R. DNA methyltransferase inhibitors and the development of epigenetic cancer therapies. J Natl Cancer Inst (2005) 97(20):1498-506. doi:10.1093/jnci/dji311

95. Curt GA, Kelley JA, Fine RL, Huguenin PN, Roth JS, Batist G, et al. A phase I and pharmacokinetic study of dihydro-5-azacytidine (NSC 264880). Cancer Res (1985) 45(7):3359-63.

96. Zambrano P, Segura-Pacheco B, Perez-Cardenas E, Cetina L, Revilla-Vazquez A, Taja-Chayeb L, et al. A phase I study of hydralazine to demethylate and reactivate the expression of tumor suppressor genes. BMC Cancer (2005) 5:44. doi:10.1186/1471-2407-5-44

97. Coronel J, Cetina L, Pacheco I, Trejo-Becerril C, González-Fierro A, de la Cruz-Hernandez E, et al. A double-blind, placebo-controlled, randomized phase III trial of chemotherapy plus epigenetic therapy with hydralazine valproate for advanced cervical cancer. Preliminary results. Med Oncol (2011) 28(Suppl 1):S540-6. doi:10.1007/s12032-010-9700-3

98. Bast RC Jr., Mills GB. Personalizing therapy for ovarian cancer: BRCAness and beyond. J Clin Oncol (2010) 28(22):3545-8. doi:10.1200/JCO.2010.28.5791

99. Watanabe Y, Ueda H, Etoh T, Koike E, Fujinami N, Mitsuhashi A, et al. A change in promoter methylation of hMLH1 is a cause of acquired resistance to platinum-based chemotherapy in epithelial ovarian cancer. Anticancer Res (2007) 27(3B):1449-52. 
100. Gifford G, Paul J, Vasey PA, Kaye SB, Brown R. The acquisition of hMLH1 methylation in plasma DNA after chemotherapy predicts poor survival for ovarian cancer patients. Clin Cancer Res (2004) 10(13):4420-6. doi:10.1158/ 1078-0432.CCR-03-0732

101. Plumb JA, Strathdee G, Sludden J, Kaye SB, Brown R. Reversal of drug resistance in human tumor xenografts by $2^{\prime}$-deoxy-5-azacytidine-induced demethylation of the hMLH1 gene promoter. Cancer Res (2000) 60(21):6039-44.

102. Dallol A, Agathanggelou A, Fenton SL, Ahmed-Choudhury J, Hesson L, Vos $\mathrm{MD}$, et al. RASSF1A interacts with microtubule-associated proteins and modulates microtubule dynamics. Cancer Res (2004) 64(12):4112-6. doi:10.1158/ 0008-5472.CAN-04-0267

103. El-Kalla M, Onyskiw C, Baksh S. Functional importance of RASSF1A microtubule localization and polymorphisms. Oncogene (2010) 29(42):5729-40. doi:10.1038/onc.2010.316

104. Vos MD, Martinez A, Elam C, Dallol A, Taylor BJ, Latif F, et al. A role for the RASSF1A tumor suppressor in the regulation of tubulin polymerization and genomic stability. Cancer Res (2004) 64(12):4244-50. doi:10.1158/0008-5472. CAN-04-0339

105. Shivakumar L, Minna J, Sakamaki T, Pestell R, White MA. The RASSF1A tumor suppressor blocks cell cycle progression and inhibits cyclin D1 accumulation. Mol Cell Biol (2002) 22(12):4309-18. doi:10.1128/MCB.22.12.4309-4318.2002

106. Li Y, Hu W, Shen DY, Kavanagh JJ, Fu S. Azacitidine enhances sensitivity of platinum-resistant ovarian cancer cells to carboplatin through induction of apoptosis. Am J Obstet Gynecol (2009) 200(2):e1-9. doi:10.1016/j.ajog.2008. 08.030

107. Frost P, Abbruzzese JL, Hunt B, Lee D, Ellis M. Synergistic cytotoxicity using 2'-deoxy-5-azacytidine and cisplatin or 4-hydroperoxycyclophosphamide with human tumor cells. Cancer Res (1990) 50(15):4572-7.

108. Kassler S, Donninger H, Birrer MJ, Clark GJ. RASSF1A and the taxol response in ovarian cancer. Mol Biol Int (2012) 2012:263267. doi:10.1155/2012/263267

109. Fang F, Balch C, Schilder J, Breen T, Zhang S, Shen C, et al. A phase 1 and pharmacodynamic study of decitabine in combination with carboplatin in patients with recurrent, platinum-resistant, epithelial ovarian cancer. Cancer (2010) 116(17):4043-53. doi:10.1002/cncr.25204

110. Matei D, Fang F, Shen C, Schilder J, Arnold A, Zeng Y, et al. Epigenetic resensitization to platinum in ovarian cancer. Cancer Res (2012) 72(9):2197-205. doi:10.1158/0008-5472.CAN-11-3909

111. Joenje H, Patel KJ. The emerging genetic and molecular basis of Fanconi anaemia. Nat Rev Genet (2001) 2(6):446-57. doi:10.1038/35076590

112. Taniguchi T, Tischkowitz M, Ameziane N, Hodgson SV, Mathew CG, Joenje H, et al. Disruption of the Fanconi anemia-BRCA pathway in cisplatin-sensitive ovarian tumors. Nat Med (2003) 9(5):568-74. doi:10.1038/nm852

113. Gupta A, Godwin AK, Vanderveer L, Lu A, Liu J. Hypomethylation of the synuclein gamma gene $\mathrm{CpG}$ island promotes its aberrant expression in breast carcinoma and ovarian carcinoma. Cancer Res (2003) 63(3):664-73.

114. Kodama J, Shinyo Y, Hashen G, Hongo A, Yoshinouchi M, Hiramatsu Y. Heparanase messenger RNA expression in epithelial ovarian tumor. Int J Mol Med (2003) 12(6):961-4. doi:10.3892/ijmm.12.6.961

115. Shteper PJ, Zcharia E, Ashhab Y, Peretz T, Vlodavsky I, Ben-Yehuda D. Role of promoter methylation in regulation of the mammalian heparanase gene. Oncogene (2003) 22(49):7737-49. doi:10.1038/sj.onc.1207056

116. Choi JH, Kwon HJ, Yoon BI, Kim JH, Han SU, Joo HJ, et al. Expression profile of histone deacetylase 1 in gastric cancer tissues. Jpn J Cancer Res (2001) 92(12):1300-4. doi:10.1111/j.1349-7006.2001.tb02153.x

117. Zhu P, Martin E, Mengwasser J, Schlag P, Janssen KP, Göttlicher M. Induction of HDAC2 expression upon loss of APC in colorectal tumorigenesis. Cancer Cell (2004) 5(5):455-63. doi:10.1016/S1535-6108(04)00114-X

118. Khabele D, Son DS, Parl AK, Goldberg GL, Augenlicht LH, Mariadason JM, et al. Drug-induced inactivation or gene silencing of class I histone deacetylases suppresses ovarian cancer cell growth: implications for therapy. Cancer Biol Ther (2007) 6(5):795-801. doi:10.4161/cbt.6.5.4007

119. Glaser KB, Li J, Staver MJ, Wei RQ, Albert DH, Davidsen SK. Role of class I and class II histone deacetylases in carcinoma cells using siRNA. Biochem Biophys Res Commun (2003) 310(2):529-36. doi:10.1016/j.bbrc.2003.09.043

120. Lee YS, Lim KH, Guo X, Kawaguchi Y, Gao Y, Barrientos T, et al. The cytoplasmic deacetylase HDAC6 is required for efficient oncogenic tumorigenesis. Cancer Res (2008) 68(18):7561-9. doi:10.1158/0008-5472. CAN-08-0188
121. Mulero-Navarro S, Esteller M. Epigenetic biomarkers for human cancer: the time is now. Crit Rev Oncol Hematol (2008) 68(1):1-11. doi:10.1016/j. critrevonc.2008.03.001

122. Chavez-Blanco A, Segura-Pacheco B, Perez-Cardenas E, Taja-Chayeb L, Cetina $\mathrm{L}$, Candelaria $\mathrm{M}$, et al. Histone acetylation and histone deacetylase activity of magnesium valproate in tumor and peripheral blood of patients with cervical cancer. A phase I study. Mol Cancer (2005) 4(1):22. doi:10.1186/14764598-4-22

123. Cincarova L, Zdrahal Z, Fajkus J. New perspectives of valproic acid in clinical practice. Expert Opin Investig Drugs (2013) 22(12):1535-47. doi:10.1517/ 13543784.2013.853037

124. Kwiecinska P, Wróbel A, Taubøll E, Gregoraszczuk EŁ. Valproic acid, but not levetiracetam, selectively decreases HDAC7 and HDAC2 expression in human ovarian cancer cells. Toxicol Lett (2014) 224(2):225-32. doi:10.1016/j.toxlet. 2013.10.035

125. Takai N, Ueda T, Nishida M, Nasu K, Narahara H. A novel histone deacetylase inhibitor, Scriptaid, induces growth inhibition, cell cycle arrest and apoptosis in human endometrial cancer and ovarian cancer cells. Int J Mol Med (2006) 17(2):323-9.

126. Ueda T, Takai N, Nishida M, Nasu K, Narahara H. Apicidin, a novel histone deacetylase inhibitor, has profound anti-growth activity in human endometrial and ovarian cancer cells. Int J Mol Med (2007) 19(2):301-8. doi:10.3892/ijmm.19.2.301

127. Marchion DC, Bicaku E, Daud AI, Sullivan DM, Munster PN. Valproic acid alters chromatin structure by regulation of chromatin modulation proteins. Cancer Res (2005) 65(9):3815-22. doi:10.1158/0008-5472.CAN-04-2478

128. Bastian L, Einsiedel HG, Henze G, Seeger K, Shalapour S. The sequence of application of methotrexate and histone deacetylase inhibitors determines either a synergistic or an antagonistic response in childhood acute lymphoblastic leukemia cells. Leukemia (2011) 25(2):359-61. doi:10.1038/leu.2010.259

129. Qian X, LaRochelle WJ,Ara G, Wu F, Petersen KD, Thougaard A, et al. Activity of PXD101, a histone deacetylase inhibitor, in preclinical ovarian cancer studies. Mol Cancer Ther (2006) 5(8):2086-95. doi:10.1158/1535-7163.MCT-06-0111

130. Plumb JA, Finn PW, Williams RJ, Bandara MJ, Romero MR, Watkins CJ, et al. Pharmacodynamic response and inhibition of growth of human tumor xenografts by the novel histone deacetylase inhibitor PXD101. Mol Cancer Ther (2003) 2(8):721-8.

131. Parker JP, Nimir H, Griffith DM, Duff B, Chubb AJ, Brennan MP, et al. A novel platinum complex of the histone deacetylase inhibitor belinostat: rational design, development and in vitro cytotoxicity. J Inorg Biochem (2013) 124:70-7. doi:10.1016/j.jinorgbio.2013.03.011

132. Dizon DS, Blessing JA, Penson RT, Drake RD, Walker JL, Johnston CM, et al. A phase II evaluation of belinostat and carboplatin in the treatment of recurrent or persistent platinum-resistant ovarian, fallopian tube, or primary peritoneal carcinoma: a Gynecologic Oncology Group study. Gynecol Oncol (2012) 125(2):367-71. doi:10.1016/j.ygyno.2012.02.019

133. Dizon DS, Damstrup L, Finkler NJ, Lassen U, Celano P, Glasspool R, et al. Phase II activity of belinostat (PXD-101), carboplatin, and paclitaxel in women with previously treated ovarian cancer. Int J Gynecol Cancer (2012) 22(6):979-86. doi:10.1097/IGC.0b013e31825736fd

134. Mackay HJ, Hirte H, Colgan T, Covens A, MacAlpine K, Grenci P, et al. Phase II trial of the histone deacetylase inhibitor belinostat in women with platinum resistant epithelial ovarian cancer and micropapillary (LMP) ovarian tumours. Eur J Cancer (2010) 46(9):1573-9. doi:10.1016/j.ejca.2010.02.047

135. Yang YT, Balch C, Kulp SK, Mand MR, Nephew KP, Chen CS. A rationally designed histone deacetylase inhibitor with distinct antitumor activity against ovarian cancer. Neoplasia (2009) 11(6):552-63. doi:10.1593/neo.09204

136. Ebert MS, Neilson JR, Sharp PA. MicroRNA sponges: competitive inhibitors of small RNAs in mammalian cells. Nat Methods (2007) 4(9):721-6. doi:10.1038/ nmeth 1079

137. Elmén J, Lindow M, Schütz S, Lawrence M, Petri A, Obad S, et al. LNA-mediated microRNA silencing in non-human primates. Nature (2008) 452(7189):896-9. doi: $10.1038 /$ nature 06783

138. Gumireddy K, Young DD, Xiong X, Hogenesch JB, Huang Q, Deiters A. Smallmolecule inhibitors of microrna miR-21 function. Angew Chem Int Ed Engl (2008) 47(39):7482-4. doi:10.1002/anie.200801555

139. Xiao J, Yang B, Lin H, Lu Y, Luo X, Wang Z. Novel approaches for genespecific interference via manipulating actions of microRNAs: examination 
on the pacemaker channel genes HCN2 and HCN4. J Cell Physiol (2007) 212(2):285-92. doi:10.1002/jcp.21062

140. Sorrentino A, Liu CG, Addario A, Peschle C, Scambia G, Ferlini C. Role of microRNAs in drug-resistant ovarian cancer cells. Gynecol Oncol (2008) 111(3):478-86. doi:10.1016/j.ygyno.2008.08.017

141. Jia W, Eneh JO, Ratnaparkhe S, Altman MK, Murph MM. MicroRNA-30c$2^{*}$ expressed in ovarian cancer cells suppresses growth factor-induced cellular proliferation and downregulates the oncogene BCL9. Mol Cancer Res (2011) 9(12):1732-45. doi:10.1158/1541-7786.MCR-11-0245

142. Cochrane DR, Spoelstra NS, Howe EN, Nordeen SK, Richer JK. MicroRNA$200 \mathrm{c}$ mitigates invasiveness and restores sensitivity to microtubule-targeting chemotherapeutic agents. Mol Cancer Ther (2009) 8(5):1055-66. doi:10.1158/ 1535-7163.MCT-08-1046

143. Leskelä S, Leandro-García LJ, Mendiola M, Barriuso J, Inglada-Pérez L, Muñoz I, et al. The miR-200 family controls beta-tubulin III expression and is associated with paclitaxel-based treatment response and progression-free survival in ovarian cancer patients. Endocr Relat Cancer (2011) 18(1):85-95. doi:10.1677/ERC-10-0148

144. Yang N, Kaur S, Volinia S, Greshock J, Lassus H, Hasegawa K, et al. MicroRNA microarray identifies Let-7i as a novel biomarker and therapeutic target in human epithelial ovarian cancer. Cancer Res (2008) 68(24):10307-14. doi:10.1158/0008-5472.CAN-08-1954

145. Boyerinas B, Park SM, Murmann AE, Gwin K, Montag AG, Zillhardt M, et al. Let-7 modulates acquired resistance of ovarian cancer to Taxanes via IMP-1-mediated stabilization of multidrug resistance 1. Int J Cancer (2012) 130(8):1787-97. doi:10.1002/ijc.26190

146. Eitan R, Kushnir M, Lithwick-Yanai G, David MB, Hoshen M, Glezerman M, et al. Tumor microRNA expression patterns associated with resistance to platinum based chemotherapy and survival in ovarian cancer patients. Gynecol Oncol (2009) 114(2):253-9. doi:10.1016/j.ygyno.2009.04.024

147. Lu L, Schwartz P, Scarampi L, Rutherford T, Canuto EM, Yu H, et al. MicroRNA let-7a: a potential marker for selection of paclitaxel in ovarian cancer management. Gynecol Oncol (2011) 122(2):366-71. doi:10.1016/j.ygyno.2011.04.033

148. Tsang WP, Kwok TT. Let-7a microRNA suppresses therapeutics-induced cancer cell death by targeting caspase-3. Apoptosis (2008) 13(10):1215-22. doi:10.1007/s10495-008-0256-z

149. Yang C, Cai J, Wang Q, Tang H, Cao J, Wu L, et al. Epigenetic silencing of miR$130 \mathrm{~b}$ in ovarian cancer promotes the development of multidrug resistance by targeting colony-stimulating factor 1. Gynecol Oncol (2012) 124(2):325-34. doi:10.1016/j.ygyno.2011.10.013

150. van Jaarsveld MT, Helleman J, Boersma AW, van Kuijk PF, van Ijcken WF, Despierre E, et al. miR-141 regulates KEAP1 and modulates cisplatin sensitivity in ovarian cancer cells. Oncogene (2013) 32(36):4284-93. doi:10.1038/onc. 2012.433

151. Huh JH, Kim TH, Kim K, Song JA, Jung YJ, Jeong JY, et al. Dysregulation of miR106a and miR-591 confers paclitaxel resistance to ovarian cancer. Br J Cancer (2013) 109(2):452-61. doi:10.1038/bjc.2013.305

152. Yu PN, Yan MD, Lai HC, Huang RL, Chou YC, Lin WC, et al. Downregulation of miR-29 contributes to cisplatin resistance of ovarian cancer cells. Int J Cancer (2013) 134(3):542-51. doi:10.1002/ijc.28399

153. Guo Y, Liao Y, Jia C, Ren J, Wang J, Li T. MicroRNA-182 promotes tumor cell growth by targeting transcription elongation factor A-like 7 in endometrial carcinoma. Cell Physiol Biochem (2013) 32(3):581-90. doi:10.1159/000354462

154. Wang YQ, Guo RD, Guo RM, Sheng W, Yin LR. MicroRNA-182 promotes cell growth, invasion, and chemoresistance by targeting programmed cell death 4 (PDCD4) in human ovarian carcinomas. J Cell Biochem (2013) 114(7):1464-73. doi:10.1002/jcb.24488

155. Snowdon J, Zhang X, Childs T, Tron VA, Feilotter H. The microRNA-200 family is upregulated in endometrial carcinoma. PLoS One (2011) 6(8):e22828. doi:10.1371/journal.pone.0022828

156. Ferlini C, Raspaglio G, Cicchillitti L, Mozzetti S, Prislei S, Bartollino S, et al. Looking at drug resistance mechanisms for microtubule interacting drugs: does TUBB3 work? Curr Cancer Drug Targets (2007) 7(8):704-12. doi:10.2174/156800907783220453

157. Li Z, Hu S, Wang J, Cai J, Xiao L, Yu L, et al. MiR-27a modulates MDR1/Pglycoprotein expression by targeting HIPK2 in human ovarian cancer cells. Gynecol Oncol (2010) 119(1):125-30. doi:10.1016/j.ygyno.2010.06.004

158. Zhu H, Wu H, Liu X, Evans BR, Medina DJ, Liu CG, et al. Role of MicroRNA miR-27a and miR-451 in the regulation of MDR1/P-glycoprotein expression in human cancer cells. Biochem Pharmacol (2008) 76(5):582-8. doi:10.1016/j. bcp.2008.06.007

159. Xie Z, Cao L, Zhang J. miR-21 modulates paclitaxel sensitivity and hypoxiainducible factor-1alpha expression in human ovarian cancer cells. Oncol Lett (2013) 6(3):795-800. doi:10.3892/ol.2013.1432

160. Marks JR, Davidoff AM, Kerns BJ, Humphrey PA, Pence JC, Dodge RK, et al. Overexpression and mutation of p53 in epithelial ovarian cancer. Cancer Res (1991) 51(11):2979-84.

161. Weinberg RA. The Biology of Cancer: Second Edition. New York, NY: Garland Science (2014). $876 \mathrm{p}$.

162. Ciucci A, De StefanoI, Vellone VG, Lisi L, Bottoni C, Scambia G, et al. Expression of the glioma-associated oncogene homolog 1 (gli1) in advanced serous ovarian cancer is associated with unfavorable overall survival. PLoS One (2013) 8(3):e60145. doi:10.1371/journal.pone.0060145

163. Sen M, Thomas SM, Kim S, Yeh JI, Ferris RL, Johnson JT, et al. First-in-human trial of a STAT3 decoy oligonucleotide in head and neck tumors: implications for cancer therapy. Cancer Discov (2012) 2(8):694-705. doi:10.1158/ 2159-8290.CD-12-0191

164. Raskatov JA, Meier JL, Puckett JW, Yang F, Ramakrishnan P, Dervan PB. Modulation of NF-kappaB-dependent gene transcription using programmable DNA minor groove binders. Proc Natl Acad Sci U S A (2012) 109(4):1023-8. doi:10.1073/pnas.1118506109

165. Moellering RE, Cornejo M, Davis TN, Del BiancoC, Aster JC, Blacklow SC, et al. Direct inhibition of the NOTCH transcription factor complex. Nature (2009) 462(7270):182-8. doi:10.1038/nature08543

166. Liu M, Wang F, Wen Z, Shi M, Zhang H. Blockage of STAT3 signaling pathway with a decoy oligodeoxynucleotide inhibits growth of human ovarian cancer cells. Cancer Invest (2014) 32(1):8-12. doi:10.3109/07357907.2013. 861471

167. Ataie-Kachoie P, Badar S, Morris DL, Pourgholami MH. Minocycline targets the NF-kappaB Nexus through suppression of TGF-beta1-TAK1-IkappaB signaling in ovarian cancer. Mol Cancer Res (2013) 11(10):1279-91. doi:10.1158/ 1541-7786.MCR-13-0239

168. Ang JE, Gourley C, Powell CB, High H, Shapira-Frommer R, Castonguay V, et al. Efficacy of chemotherapy in BRCA1/2 mutation carrier ovarian cancer in the setting of PARP inhibitor resistance: a multi-institutional study. Clin Cancer Res (2013) 19(19):5485-93. doi:10.1158/1078-0432.CCR-13- 1262

Conflict of Interest Statement: The authors declare that the research was conducted in the absence of any commercial or financial relationships that could be construed as a potential conflict of interest.

Received: 23 January 2014; accepted: 20 March 2014; published online: 08 April 2014. Citation: Nguyen HT, Tian G and Murph MM (2014) Molecular epigenetics in the management of ovarian cancer: are we investigating a rational clinical promise? Front. Oncol. 4:71. doi: 10.3389/fonc.2014.00071

This article was submitted to Women's Cancer, a section of the journal Frontiers in Oncology.

Copyright $\odot 2014$ Nguyen, Tian and Murph. This is an open-access article distributed under the terms of the Creative Commons Attribution License (CC BY). The use, distribution or reproduction in other forums is permitted, provided the original author(s) or licensor are credited and that the original publication in this journal is cited, in accordance with accepted academic practice. No use, distribution or reproduction is permitted which does not comply with these terms. 